Discussion Paper No. 08-039

\title{
The Employment Consequences of Seniority Wages
}

Thomas Zwick

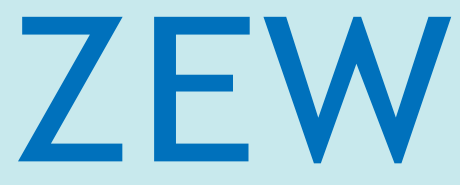

Zentrum für Europäische Wirtschaftsforschung $\mathrm{GmbH}$

Centre for European

Economic Research 
Discussion Paper No. 08-039

\title{
The Employment Consequences of Seniority Wages
}

\author{
Thomas Zwick
}

Download this ZEW Discussion Paper from our ftp server:

ftp://ftp.zew.de/pub/zew-docs/dp/dp08039.pdf

Die Discussion Papers dienen einer möglichst schnellen Verbreitung von neueren Forschungsarbeiten des ZEW. Die Beiträge liegen in alleiniger Verantwortung der Autoren und stellen nicht notwendigerweise die Meinung des ZEW dar.

Discussion Papers are intended to make results of ZEW research promptly available to other economists in order to encourage discussion and suggestions for revisions. The authors are solely responsible for the contents which do not necessarily represent the opinion of the ZEW. 


\section{Nontechnical Summary}

In an international comparison, German workers have a long seniority and face larger problems to find a new job when they are older - the relative unemployment rate of people older than 55 is clearly higher in comparison to the average unemployment rate than in any other OECD country. Both facts point at a potentially important impact of deferred compensation on the employee structure and hiring behaviour. Firms that defer compensation pay their older employees with long seniority higher wages than their productivity, in exchange of lower wages at the beginning of their careers. This provides them with an efficient mechanism to motivate and retain their employees. In this paper the deferred wage hypothesis is tested indirectly by looking at the employment structure and hiring consequences of high seniority wages. Our main assumption is that firms with deferred compensation have a relatively steep seniority-wage profile in comparison to their competitors. As a consequence, they can keep their employees longer and hire less older unemployed (because they are too expensive if they are paid according to the insiders with longer tenure but the same age). In order to calculate differences in seniority wages between establishments and their consequences on the employment structure and hiring behaviour, this paper combines two strains of the literature. The first strain separates seniority and job matching wage effects on the basis of individual data, but cannot look at employment consequences. The second strain explains the employment structure on the basis of establishment data, but cannot properly calculate seniority wages. This paper uses linked employer-employee data, aggregates individual seniority wages to the establishment level, and correlates them with the establishment employment structure. From the individual wage estimations that are performed according to the two most influential seniority wage estimation approaches, we learn that in an international comparison German firms pay relatively high seniority wages. In the estimations on the consequences of seniority wages, it finds according to the deferred compensation hypothesis that establishments with stronger seniority wages have a higher tenure but hire less older employees. These results are obtained by calculating all variables as deviations from sector means. These results are taken as evidence that at least some German establishments use deferred payments and hereby retain workers but lock out older employees. 


\section{Nichttechnische Zusammenfassung}

Im internationalen Vergleich verbleiben deutsche Beschäftigte lange im gleichen Betrieb und haben größere Schwierigkeiten eine neue Stelle zu finden, wenn sie älter sind. Die Arbeitslosenquote Älterer über 55 Jahre im Vergleich zur durchschnittlichen Arbeitslosenquote ist in Deutschland höher als in allen anderen OECD Ländern und das Arbeitsvolumen dieser Personengruppe ist vergleichsweise gering. Beide Fakten deuten darauf hin, dass Unternehmen ihre älteren und lange im Unternehmen verbliebenen Beschäftigten über ihrer Produktivität entlohnen. Im Gegenzug ist die Entlohnung in den ersten Beschäftigungsjahren relativ gering. Dieses steile Entlohnungsprofil gibt den Unternehmen einen effizienten Mechanismus an die Hand, ihre Beschäftigten an den Betrieb $\mathrm{zu}$ binden und $\mathrm{zu}$ motivieren. In diesem Papier wird die Hypothese, dass Betriebe diese steilen Entlohnungsprofile haben, indirekt getestet, indem die Konsequenzen der Senioritätsentlohnung auf Beschäftigungsstruktur und Einstellungsverhalten untersucht werden. Die Hauptannahme ist hierbei, dass Unternehmen mit einem steilerem Lohn-Senioritätsprofil als ihre Mitbewerber ihre Beschäftigten relativ lange binden können, jedoch kaum ältere Beschäftigte einstellen (weil diese zu teuer sind, falls sie den gleichen Lohn bekommen wie die bereits länger im Betrieb Beschäftigten gleichen Alters). Um den Einfluss der Senioritätsentlohnung auf die Beschäftigungsstruktur und Einstellungsverhalten zu berechnen, werden zwei Literaturstränge miteinander verknüpft. Der erste Strang trennt auf der Basis von Individualdaten die Lohneffekte von Seniorität und Selektivität, kann aber die Beschäftigungsauswirkungen nicht betrachten. Der zweite Strang erklärt zwar die Beschäftigungsstruktur auf der Basis von Unternehmensdaten, kann aber Senioritätslöhne nicht einwandfrei berechnen. In diesem Beitrag werden verknüpfte Betriebs- und Beschäftigtendaten genutzt, um individuelle Senioritätslöhne auf Unternehmensebene zu aggregieren und anschließend den Zusammenhang mit der Beschäftigtenstruktur zu prüfen. Die Berechnungen zeigen, dass deutsche Unternehmen im internationalen Vergleich hohe Senioritätslöhne bezahlen. Die Konsequenzen der Senioritätslöhne auf Betriebsebene hingegen zeigen, dass Unternehmen mit stärkerer Senioritätsentlohnung ihre Beschäftigten länger binden können, jedoch weniger ältere Beschäftigte neu einstellen. Die Schlussfolgerung daraus ist, dass zumindest in einigen deutschen Unternehmen steile Lohnprofile ältere Arbeitslose ausgrenzen. 


\title{
The employment consequences of seniority wages
}

\author{
Thomas Zwick \\ Centre for European Economic Research (ZEW) \\ zwick@zew.de
}

June 2008

\begin{abstract}
This paper combines two strains of the literature on the employment effects of deferred compensation. The first strain separates seniority and job matching wage effects on the basis of individual data, but cannot look at employment consequences. The second strain explains the employment structure on the basis of establishment data, but cannot properly calculate seniority wages. This paper uses linked employeremployee data, aggregates individual seniority wages to the establishment level, and correlates them with the establishment employment structure. According to the deferred compensation hypothesis this paper finds that establishments with stronger seniority wages have a higher tenure but hire less older employees.
\end{abstract}

Key-Words: Seniority Wages, Employment Structure, Linked Employer-Employee Data

JEL Codes: J14, J21, J31

This paper was financially supported by the Akademiegruppe Altern in Deutschland. I am indebted to Uschi Backes-Gellner, Axel Börsch-Supan, Karsten Hank, James, Heckman, Hendrik Jürges, Werner Neus, and Wolfgang Streeck for their helpful suggestions. I also thank the Research Data Centre (FDZ) of the Federal Employment Agency at the Institute for Employment Research (especially Peter Jacobebbinghaus and Dirk Oberschachtsiek) for their support with the analysis of the data. The data basis of this publication is the Cross Section Model (version 1) of the Linked Employer-Employee Data of the IAB (LIAB, years 1997-2004). Data access was via guest research spells at FDZ and afterwards via controlled data remote access at FDZ. 


\section{Introduction}

Unemployment duration, wage loss after unemployment, and the risk to work part-time increase and the chances to find a new job decline with age (Farber, 1997; Hirsch et al., 2000). This phenomenon frequently is associated with wages being higher than the value of the workers' marginal product beyond a certain tenure length. Lazear (1979, 1981) labels this wage pattern "deferred payment" and explains it by long-term implicit contracts that solve the agency problem by shifting compensation to the end of the contract. Establishments that use deferred payment should be characterised by a longer average tenure of employees and a lower motivation to hire older employees.

It is notoriously difficult to measure individual productivity and therefore a direct test of the hypothesis that firms defer payments in order to solve their agency problem is hard to find. ${ }^{1}$ The empirical literature on the presence and consequences of deferred payment therefore is split into two strains that partly contradict themselves (Hutchens, 1989). One strain focuses on the estimation of earnings tenure profiles (Topel, 1991; Altonji and Shakotko, 1987; Dustmann and Pereira, 2005). These papers show that the individual wage (increase) has to be separated into the seniority component and the match quality or experience component. This split takes into account that employees who fit well into jobs tend to stay longer at the employer. Although some of the estimated rather flat earnings tenure profiles cast doubt on the empirical relevance of deferred earnings, they do find a large variance of wage profiles between individuals. These contributions are based on individual data and therefore do not have establishment information that is necessary to detect consequences of variations in wage tenure profiles on the establishment employment structure.

The other strain of empirical papers assumes that deferred earnings exist (in certain enterprises or for certain jobs) and tests indirectly if (indicators of) seniority wages or other employee and establishment characteristics have consequences for the employment opportunities of older employees, retirement rules, and the age structure of enterprises (Hutchens, 1986; Hirsch et al., 2000). They are typically based on establishment data and use aggregate indicators, such as the average wages of older

\footnotetext{
${ }^{1}$ Among the few direct comparisons between wage and productivity profiles using data from one single firm are Medoff and Abraham (1980), Lazear (1999), and Shaw and Lazear (2007).
} 
workers versus the aggregate wages of younger workers, or the average wage increase between workers aged 30 and workers aged 50. These papers cannot separate seniority and selectivity effects in the seniority wage indicators. Therefore the seniority wage indicators they use might be biased.

This paper for the first time combines both literature strains. It first measures individual earnings tenure profiles separating them from the selectivity effect. Then the individual seniority wages are aggregated to the establishment level. Finally, it is tested if differences in the aggregated earnings tenure profiles lead to consequences for the establishment employment structure and the chances of older workers to find new jobs. According to the deferred wage hypothesis, establishments with higher seniority wage should have a higher average tenure because employees are motivated to stay longer in the same establishment, while they hire less older employees because they are relatively expensive (Hutchens, 1986).

This empirical approach is only viable since the advent of linked employeremployee data because these data sets provide the crucial information on the individual wage, seniority and experience characteristics of all employees in an establishment necessary to calculate individual seniority wages and aggregate them to an indicator of seniority wages at the establishment level. In addition, these data give us the employment and hiring characteristics at the establishment level needed to test the consequences of deferred wage hypothesis.

This paper has the following structure. The next part explains the theoretical notion of deferred payments and its consequences for the employment structure of enterprises. It also presents in detail the two different strains of the empirical literature tackling this topic so far. The third part explains the empirical estimation strategy and the fourth part presents the linked employer employee panel data set used. The fifth part contains the empirical analysis on the employment effects of seniority wages and the sixth part concludes.

\section{Background}

According to Lazear (1979, 1981), employers and employees may enter into implicit contracts, whereby workers receive a wage that is less than the value of the worker's marginal product at the beginning of the contract and greater than the value of marginal 
product at the end. The employees are indifferent to work for an employer with implicit contracts or an employer that pays wages equal to the marginal product value if the (expected) present value of both paths is equal. The steeper wage path of firms with deferred compensation changes the workers' incentive structure, however. It induces them to work harder and remain honest with the firm in order to finally obtain the high wage. Workers who shirk or steal run the risk of being caught and fired and forgoing the payments that come at the end of the contract. This change in behaviour efficiently solves the agency problem and makes more costly alternatives such as efficiency wages or control mechanisms redundant. Deferred compensation therefore increases the value created over the life cycle and probably also the life time wealth for the employee if the employer shares part of the increased value. A strong increase of wages with seniority, however, renders older workers costly. The firms pay the high wages for the insiders with a long tenure in order to fulfil the implicit contract. They have no motivation to hire older workers, however, because their productivity is lower than their wages at least if firms do not want to discriminate between workers' wages on the basis of equity considerations. Especially in Germany, works councils and collective bargaining contracts support earnings equality for employees with similar observable characteristics and in similar tasks and hereby contribute to the relatively small wage dispersion (Addison et al., 2006).

Delayed payment contracts therefore should induce firms to employ older employees but not hire them (Hutchens, 1986). Seniority wages can therefore be associated with long job tenures, mandatory retirement rules and a lower willingness of establishments to hire older workers. Inspired by the theory of implicit contracts, there is a broad empirical literature that tries to find out if wages are indeed deferred, or in other words if wages increase stronger with tenure than productivity for those who stay with the same employer. An alternative hypothesis is that enterprises pay seniority wages purely in order to match increases in productivity stemming from higher experience or specific human capital acquired during the job (Carmichael, 1983) or as an insurance device (Harris and Holmstrom, 1982). It may be possible that firms increase seniority wages according to the productivity increases and nevertheless do not hire older employees and have high average employee tenure. This may be the case if specific skills are important for productivity in these firms and older employees do not have enough time left to acquire these skills gainfully. It may nevertheless be the case 
however that these establishments pay seniority wages beyond the productivity increase in order to attract and keep suitable employees (Carmichel, 1983).

The empirical literature that tests the deferred wage hypothesis is split into two strains so far. The first line of papers focuses on the estimation of individual seniority wages and explores whether wages increase with seniority at all (Abraham and Farber, 1987). These papers stress that workers with comparatively high wages tend to remain in their jobs. As the high wages can be paid right since the start of the new job, this selfselection process induces a positive bias in the measurement of seniority wages. Altonji and Shakotko (1987) use the individual variation of tenure over a given job as instrumental variable in order to correct for unobserved individual and job characteristics that affect wages. The instrumental variable estimator for the impact of tenure on wages based on the 1968 - 1981 waves of the Panel Study of Income Dynamics indeed is much lower than the least square estimates and the experience slopes are steeper. This leads the authors to the conclusion that general labour market experience and job shopping account for the bulk of wage growth over a career. Dustmann and Pereira (2005) note that also the experience variables might be endogeneous in the wage equation and they accordingly also instrument experience by the deviation from the individual experience mean. They find on the basis of the British Household Panel Survey and the German Socio-Economic Panel for the period 19911997 that returns to seniority are close to zero in both countries on average. Parent (2000) argues that industry-specific capital plays a larger role than tenure in one firm. Indeed, re-estimating tenure earnings profiles using the estimation approach by Altonji and Shakotko (1987) and additionally controlling for workers who change industry when they change jobs, the tenure effect is even further reduced. But since he uses data from the National Longitudinal Survey of Youth and the Panel Study of Income Dynamics (PSID), his results cannot indicate the tenure earnings profile for older workers.

Topel (1991) chooses an alternative approach measuring wage growth instead of wage levels. He separates the tenure and experience effect on wages of those employees who stay in the same firm. On the basis of the PSID, he first estimates the joint impact of tenure and experience on individual wages and then deducts the impact of initial experience on this effect from a second estimation step. Lefranc (2003) argues that Topel's (1991) results might be biased because Topel uses yearly averages of wages 
instead of hourly wages at the day the other individual characteristics are measured. The tenure estimates are indeed smaller for hourly wages than average yearly wages. Lefranc (2003) also estimates the returns to seniority for the USA on the basis of the PSID for 1981-1992 and for France on the basis of the enquêtes d'emploi for 19901997. Williams (2004) argues that the tenure coefficients in Topel (1991) might be biased downwards by job match heterogeneity and biased upwards by individual heterogeneity. In order to check the bias due to individual heterogeneity, he instruments initial experience in the second estimation step by current individual experience. On the basis of the British Household Panel Survey for 1991-1998, he finds that indeed the experience effect increases in the instrumental variable version and analogously the tenure effect decreases. The impact of seniority on wages found by the papers based on Topel's approach is around one or two percent per year and therefore slightly higher than the effect around zero calculated by the authors on the basis of Altonji and Shakotko's approach.

The papers discussed so far are based on individual data sets without establishment characteristics. They therefore cannot calculate the employment consequences of seniority wages or compare the steepness of wages and productivity over tenure. One approach to directly identify the wage and productivity patterns is to use case study data from enterprises in which individual productivity can be measured. Medoff and Abraham (1980) present one of the few papers. They find that a worker's subjective performance rating relative to others in a job grade does not increase with time in the job grade. Earnings relative to others in the grade tend to increase with time in the grade, however. Lazear (1999) and Shaw and Lazear (2007) show that the slope of tenure in the earnings regression is steeper than the slope of tenure in the productivity regression in a car glass repair enterprise. It remains unclear, however, if these findings can be transferred to other firms and sectors.

Hellerstein et al., (1999) pursue another estimation strategy. In non-linear estimations they compare the productivity impact of prime-aged workers with the impact of older workers with their differences in relative wages. They use a US linked employer-employee data set for 1989 from the Census of Population and the Longitudinal Research Database. They find that productivity and earnings rise at the same rate over the life cycle for both groups of workers. Hellerstein and Neumark (2004) use a similar estimation approach on the basis of the large and representative US 
1990 Decennial Employer-Employee Dataset. They find that the estimated relative wage profile is steeper than the relative productivity profile, consistent with models of deferred wages.

The second strain of the literature indirectly measures deferred compensation by looking at the employment consequences of (indicators of) seniority wages. Lazear (1979) finds a positive correlation between individual mandatory retirement/pension plans and the difference between individual average job wage growth and predicted job wage growth. The predicted average job wage growth is derived from a regression explaining the difference between the topical wage of older workers and the wage in the first full-time job divided by experience. The explanatory variables are individual characteristics such as qualification, sex or the age at the first job. Lazear uses individual data from the US Longitudinal Retirement History Survey, 1969-71. Hutchens (1986) uses the 1970 one-in-100 census file in order to construct slightly less than 3000 three-digit industry occupation pairs. According to the theory of deferred payment, he finds that industry-occupation pairs that have relatively few recently hired workers over age 55 in relation to all workers over age 55 are characterised by pensions, mandatory retirement, high tenure and high wages per hour for older employees. Note that he cannot exactly measure tenure because changes from one employer to the other are only accounted for if the employee changes the industry or the occupation. Hutchens (1987) finds some indirect evidence for the hypothesis that firms use deferred payment for jobs that cannot easily be monitored. He uses the repetition-of-tasks variable as an indicator for the extent to which the technology used in a given job is conducive to monitoring worker effort. This variable is not only negatively correlated with the probability of pensions and mandatory retirement but also with the length of job tenure and the level of wages for older workers. The evidence is based on the 1971 wave of the NLS older male data which contains data from almost 3000 workers. Hirsch et al. (2000) calculate the impact of wage tilt (the rate of wage growth after controlling for other measurable wage determinants) on the age structure. On the basis of various micro-level Current Population Survey files and other data sets, they find that occupations with steeper wage profiles are less likely to have a high proportion of older workers and are less likely to hire older workers. Their measures are all aggregated to the occupation level and the tenure earnings function is based on potential experience because tenure and experience are unknown. Finally, Daniel and Heywood (2007) use 
the 1998 UK WERS linked employer employee data set in order to test the seniority wage hypothesis on the establishment level. They find that firms that defer compensation indeed hire a smaller share of older workers. They do not have direct indicators for seniority wages, however, but only know the average wage increase for all employees in the establishment.

\section{Estimation Strategy}

The strength of deferred wages should affect the employee structure and hiring behaviour if indeed the productivity of the employees grows by a lower rate than the wages. Our basic assumption is that we can compare the seniority wages within a sector. A steeper seniority wage profile of an establishment than that of the average establishment in a sector is interpreted as an indication that this enterprise offers a wage-seniority pattern that exceeds productivity growth. More specifically, we test the following hypotheses: If an enterprise pays steeper tenure earnings profiles than the average enterprise in its sector, this should lead (1) to a higher average tenure of the employees and (2) a lower probability of hiring older workers in comparison to the average enterprise in the sector (Hutchens, 1986; Hirsch et al., 2000). The impact of deferred compensation on the age structure remains unclear (3) because longer seniority and a smaller share of older workers hired constitute two countervailing effects whose net outcome cannot be predicted theoretically.

The basic idea to test the deferred wage hypothesis is to estimate individual seniority wages according to the two most influential estimation approaches (Topel, 1991; Altonji and Shakotko, 1987) in a first step. In a second step the individual seniority wages are aggregated to the enterprise level. Finally, the impact of the aggregate enterprise seniority wages is estimated on enterprise average tenure, average age, and hiring chances of older employees. Here deviations from the sector means are used for all variables.

As indicated above, Topel (1991) argues that tenure is endogeneous in an earnings regression. In order to separate the tenure and the experience effect, first the growth of real wages $\Delta w$ is estimated for those workers who stay with the same 
employer by the change in tenure $\Delta t$ and experience $\Delta e$ (and their squares, triples, and quadruples) $)^{2}$ :

$$
\Delta w_{i}=\alpha_{1} \Delta t_{i}+\alpha_{2} \Delta t_{i}^{2}+\alpha_{3} \Delta t_{i}^{3}+\alpha_{4} t_{i}^{4}+\beta_{1} \Delta e_{i}^{2}+\beta_{2} \Delta e_{i}^{3}+\beta_{3} \Delta e_{i}^{4}+\varepsilon_{i}
$$

From equation (1), the cumulated average wage increase since the present job began is calculated for every employee depending on experience and tenure $\Delta \Omega$. Please notice that we cannot distinguish yet between the tenure and the experience effect but only observe their combined linear effect in $\alpha_{1}$ because both measures increase by one from year to year for those who stay in the same firm.

The average predicted wage increase in the present job - given the current tenure and experience - is then deducted from the current wage in order to obtain the predicted wage at the beginning of the present job (we have to estimate the initial wage because it lies outside of our observation period for employees with longer seniority). The calculated wage at the beginning of the topical job $t=0$ is the endogeneous variable in the second equation that is explained by the experience at the beginning of the current job $e_{0}$ and a vector $F$ of further individual and enterprise characteristics:

$$
w_{i}-\Delta W_{i}=\beta_{0} e_{0 i}+\delta^{\prime} F_{i}+\zeta_{i}
$$

The true seniority wage minus the experience effect is finally calculated by deducting the experience effect on the initial wage level $\beta_{0}$ in the second equation from the joint seniority and experience effect $\alpha_{1}$.

The second estimation step might bias the measured tenure effect downwards because job matches are heterogeneous and upwards because individuals are heterogeneous (Williams, 2004). In order to avoid these biases, Topel (1991) proposes to instrument initial experience with current experience in the second stage. In a robustness check, initial experience in equation (2) is instrumented accordingly.

In the next step, the predicted error terms of equation (1) are taken, i.e. the positive or negative deviations from the average predicted wage increase $\widehat{\varepsilon_{i}}$. Then the individual residuals are aggregated to the average residuals on the establishment level $\sum_{j} \hat{\varepsilon}_{i \in j}$. Then the deviation of the average enterprise residual from the sector and year average is calculated. It is therefore possible that if some employees in one enterprise earn more and some earn less than the average seniority wage in the sector and year, the aggregate

\footnotetext{
${ }^{2}$ Results are roughly the same if we de-trend wages using year dummies in order to remove the
} 
effect is zero. In the final step, the aggregate deviation $d_{j}=\hat{\varepsilon}_{i}-\sum_{i} \hat{\varepsilon}_{i \in j}$ from the sector and year mean is taken as one of the establishment characteristics used to explain the establishment employment and hiring structure $x_{j}$ (compare Hutchens, 1986; Hirsch et al., 2000):

$$
x_{j}=\chi d_{j}+\phi^{\prime} G_{j}+\varphi_{j}
$$

The other covariates are the typically used establishment characteristics to explain the employment structure and the hiring strategy of firms: the share of foreigners, the profit situation, the presence of a works council, an export dummy and several qualification characteristics of the work force.

Altonji and Shakotko (1987) and Dustmann and Pereira (2005) assume that the worker-firm specific match is time-invariant. They use deviations from the individual job means in tenure and experience (and their higher order terms) as instruments in order to solve the problem of endogeneity in the earnings equation. In the second estimation approach to calculate seniority wages, the individual wage is explained by tenure $t$, and tenure square $t^{2}$, a dummy old that indicates if the employee works for the enterprise longer than one year, experience $e$ and their higher orders as well as additional establishment and individual characteristics $X$ :

$$
w_{i}=\alpha_{1} t_{i}+\alpha_{2} t_{i}^{2}+\alpha_{3} \mathrm{old}_{i}+\beta_{1} \mathrm{e}_{i}+\beta_{2} e_{i}^{2}+\beta_{3} e_{i}^{3}+\gamma^{\prime} \mathrm{X}_{i}+\varepsilon_{i} .
$$

The problem of the endogeneity of tenure in the wage regression is solved in this paper following Altonji and Shakotko (1987) by instrumenting $t, t^{2}$ and old by their deviation from the individual means. Dustmann and Pereira (2005) argue that also the experience terms should be instrumented by the same internal instruments. In this paper therefore equation (4) is calculated by two instrumental variables regression using the deviations as instruments for tenure as well as tenure and experience. In order to calculate the establishment deviations from the average seniority wages, interaction terms are added between the individual tenure term (respectively the instrumented tenure term) and an enterprise indicator $f_{j}$ :

$$
w_{i}=\alpha_{1} t_{i}+\alpha_{2} t_{i}^{2}+\alpha_{3} \mathrm{old}_{i}+\beta_{1} \mathrm{e}_{i}+\beta_{2} e_{i}^{2}+\beta_{3} e_{i}^{3}+\gamma^{\prime} \mathrm{X}_{i}+\delta_{j}\left(t_{i} \bullet f_{j}\right)+\varepsilon_{i} .
$$


An enterprise is labelled now as paying a high seniority wage if the coefficient $\delta_{\mathrm{j}}$ of the interaction term is positive and a dummy variable is created accordingly. Please note that we need as many interaction terms as enterprises in the data set.

In the last step, the regressions on the employment structure of the enterprise are executed similarly to those in equation (3). Here we explain the employment structure and hiring behaviour using the dummy variable for high seniority enterprises derived from equation (5) and the same additional establishment characteristics as explanatory variables. Again, we use deviations from the year and sector means for all variables including the high seniority wage dummy variable.

\section{Data}

In order to analyse seniority wages in Germany, this paper uses the waves 1997-2004 of the linked employer-employee data set of the Institut für Arbeitsmarkt- und Berufsforschung (LIAB). We choose the cross section version of this data set, which means that we have one observation per year (on June 30th) for almost all employees in the establishments observed (see Alda et al., 2005 for details). On the establishment level, the LIAB uses the representative survey data of the IAB establishment panel. This panel entails questions on value added, industrial relations, sector, average employee characteristics and expectations of the managers. The establishment data are linked with a common identifier to the individual information. The individual level uses official data of the IAB employment register. Yearly information on individual wages, qualification, gender, tenure, experience, and age can therefore be linked to the employer data. Altogether we have almost 7 Mio. employees in more than 8,500 establishments.

We know individual daily earnings at the survey date. These wages are deflated by the official wage inflation data from the Federal Statistical Office. About $8 \%$ of the observations have censored wages on the social contribution ceiling (only the ceiling value is reported in the data set and not the true earnings). Those censored wages are multiply imputed (compare Gartner, 2005) by defining 20 cells for different gender, qualification (five groups), and nationality. For each cell censored wage Tobit regressions are estimated separately including the covariates tenure, tenure square, age, sector (16 dummies), an East Germany dummy, and three dummies for the qualification 
level. Also tenure and experience are censored. For employees in West Germany experience and tenure are known since January $1^{\text {st }} 1970$ and for East Germany since January $1^{\text {st }} 1990$. This means that between $16 \%$ (1997) and 7\% (2001) of the West German and between 46\% (1997) and 28\% (2001) of the East German employees have censored values. We account for censoring by also multiply imputing the censored values. The calculated imputed values for wages, experience and tenure might lead to excess variance in time differences and therefore only the first imputed value of several censored values in a row is taken. For the following values the same (inflation corrected) wage is taken instead of a separately calculated imputed wages and for tenure and seniority, one year is added to the base value. In order to test the robustness of our results, all regressions have also been executed without any observations with censored values for wages, tenure, and experience. The results were qualitatively the same and led to slightly higher estimated seniority wages (results available on request).

We only include employees working full time because we do not know the working hours of those working part time. In the tradition of Topel (1991) only employees aged 18-60 are included in order to avoid strong selectivity at the age fringes. We exclude the East German employees because their experience and tenure information is heavily censored and wage increases are dominated by the quick catch-up process between East and West German wages in the 90s. We also exclude employees in public enterprises because they received an automatic seniority bonus in the observation period and employers were not free to decide on the steepness of the seniority bonus. Apprentices are excluded because they have a strong wage increase after completing their apprenticeship. Finally, employees whose wages increased or decreased by more than $200 \%$ from year to year are excluded.

\section{The Impact of Seniority Wages on the Employment Structure of}

\section{Firms}

First the seniority wages are calculated analogously to the approaches by Topel (1991) and Altonji and Shakotko (1987). This allows us to compare the results with those obtained in papers using the same estimation techniques for different countries or using other German data and observation periods. The average tenure/experience effect of an additional year at the same employer calculated according to equation (1) is about $11 \%$ 
in Germany (compare Table 1). This effect lies between that calculated by Lefranc (2003) for the USA (about 12\% for 1981-1992) and France (about 5\% for 1990-1997). ${ }^{3}$ The effect of initial experience on the initial wage according to equation (2) is about $6 \%$ (see Table 2). This means that initial experience accounts for about half of the seniority wage effect. This share of selectivity on seniority wages is comparable to that found by Lefranc (2003) for France but smaller than that for the USA. After deducting the selectivity effect from the total effect, we obtain a seniority wage effect per annum of about 4\%. This effect is higher in Germany than in comparable estimations for France or the USA - here seniority wages are measured at around 1-2\% (Lefranc, 2003), see the lower part of Table 2 for the estimated cumulative returns to job tenure or appendix figure 1 which also includes results for the UK derived from Williamson (2004).

If we instrument the initial experience variable by current experience, this reduces the estimated initial experience coefficient $\beta_{0}$ from about $6 \%$ to about $4 \%$ in equation (2), but has no impact on the relative seniority measures from estimation step one. The LIAB entails tenure and experience, but not the sector of the previous employer and therefore we cannot include industry experience as an additional covariate (Parent, 2000; Dustmann and Meghir, 2005).

The OLS earnings estimation analogous to Altonji and Shakotko (1987) leads to comparably low and concave seniority wages, a high impact of the first year dummy and significantly positive experience terms in Germany (compare Table 3). The tenure coefficients decrease if they are instrumented, while the experience terms increase (IVten). This is also found by Altonji and Shakotko (1987). If we additionally take endogeneity of experience into account by instrumenting the experience terms (IVtenexp, compare Dustmann and Pereira, 2005), the tenure effect stays insignificant while the experience coefficients decrease (according to the findings in the previous literature). Table 4 shows that considering the impact of tenure on wages for all workers lead to a much smaller impact of tenure on wages than looking at wage increases of stayers (compare Table 2). The tenure impact estimated for the period 1998-2003 on the basis of the LIAB is again slightly higher than that calculated by Dustmann and Pereira

\footnotetext{
${ }^{3}$ The results derived by Topel (1991) for the USA 1968-1983 are not comparable because he uses average hourly wages instead of the exact hourly wages at the estimation point in time. Lefranc (2003) also demonstrates that the estimation period plays a pervasive role in the calculations (repeating the estimation by Topel for the period 1981-1992 reduces the average coefficient from about $12 \%$ to $4 \%$ ).
} 
(2005) for Germany 1991-1997 and by Altonji and Shakotko (1987) for the USA (see Table 4). ${ }^{4}$

Seniority wages are therefore clearly over-estimated if we do not take selectivity into account. It also seems that wages increase with seniority in Germany and that this increase is at least not lower than in the USA, UK or France. This corresponds with what the OECD (2005) concludes on the basis of cross section analyses without taking selectivity issues into account. The differences between the countries might be due to differences in the data or the observation period and therefore should not be overstressed. Taken at face value the stronger seniority wages in the international comparisons should lead to relatively long average establishment tenure and less opportunities for older unemployed to find new jobs in Germany. This is what we indeed find: average seniority in Germany is comparable with that in Western European continental countries but higher than in UK, Scandinavian countries and most countries in Eastern Europe (OECD, 2008). The relation between the unemployment rate of older people aged between 50-64 in comparison to the average unemployment rate is the highest of all OECD countries. In 2006, the German ratio was more than 1.2 and about 0.7 on the OECD average - the only other OECD country with a ratio above 1 was the Netherlands (OECD, 2008). In addition, the relative labour volume of older employees in Germany is low in an international comparison (Schief, 2006). These descriptive statistics provide first evidence that relatively steep seniority wages lead to a relatively strong reaction of establishments with respect to their employee structure and hiring behaviour.

It may well be that not all establishments use deferred payments and therefore we should allow for variation in the wage-seniority profile across establishments (Hutchens, 1986) instead of looking at averages. A much stronger test of the deferred wage hypothesis therefore is if establishments in the same sector with different seniority wages also differ with respect to their employment structure and hiring behaviour. In the next step therefore the residuals from the individual wage equation (1) are aggregated to the establishment level and then deviations from the sector and year

\footnotetext{
${ }^{4}$ Please note that Dustmann and Pereira (2005) use a slightly different estimation specification than Altonji and Shakotko (1987). If we replicate their IVtenexp specification, the cumulative returns to tenure are: 0.06 (5 years), 0.07 (10 years), 0.05 (15 years), 0.03 (20 years) and therefore slightly lower than those according to the Altonji and Shakotko specification and even decreasing like in the Dustmann and Pereira specification.
} 
means are constructed. This indicator has mean zero and variance 0.02 . It is used as a covariate together with five qualification share indicators, an export dummy, the share of foreigners in the firm and dummies indicating if there is a works council or if the establishment is profitable. These variables are all taken as deviations from the sector and year means. After aggregating the error terms in equation (1) to the sector means, it becomes obvious that the investment and consumption goods sector, the banking and insurance industry, and the rest category "other services" (for example personal services) pay higher seniority wages than the other sectors. Especially low seniority wages are paid in the sectors agriculture and forestry, hospitality, and education and training.

An OLS regression then explains the employee structure and hiring behaviour of the establishments (compare Table 5). The coefficients of the seniority wage variable confirm the hypotheses: higher seniority wages have a significant positive impact on average tenure and a significant negative impact on the share of newly hired old employees on all older employees and of the share of newly hire old employees on all newly hired employees. Obviously both countervailing effects (longer seniority vs. less older employees hired) have a similar strength because seniority wages have no impact on the average age and the share of employees aged fifty years or older. By using a cluster command, it is taken into account that several observations might stem from the same firm but from different years. In order to control that the pooling of observations from different years in this estimation step is innocuous, the regressions are recalculated using only observations from the year 2001. This leads qualitatively to the same results (not shown here). The estimations explaining the employment structure and the hiring strategy are partly not very well determined, the other covariates show plausible signs, however.

In the second part of the approach based on Altonji and Shakotko, the OLS regression according to equation (5) is estimated including interaction dummies for individual tenure and the about 3000 establishments the employees worked in $2001 .^{5}$ Then a new dummy variable which equals one if the tenure/establishment interaction term is larger than zero or in other words the establishment has a higher seniority wage than the average establishment is created. This procedure is repeated using the

\footnotetext{
${ }^{5}$ We have to exclude the observations from the other years because memory constraints do not allow us to run the regression with more than 6000 establishment interaction terms.
} 
instrumental variable regression including interaction terms between the instrumented tenure and the establishment identifiers. In the OLS regression around $52 \%$ of the establishments are marked as high seniority enterprises and in the IV regression $44 \%$. If we compare the establishments marked as paying relatively high seniority wages, $62 \%$ are marked the same in both estimation approaches. If we look at the shares of enterprises with more than average seniority wage payments by sector, we get the same three sectors with more than average shares and the three sectors with below than average shares as in the previous approach.

In a last step, the employment structure and hiring behaviour is explained using the seniority wage dummy derived from equation (5) and the other establishment characteristics (see Table 6). Again all variables are taken as deviations from sector means. Also these regressions show that a high seniority wage has a positive impact on the average employee tenure and a negative impact on the openness of the enterprise towards hiring older workers. A higher seniority wage does not affect the average age of the employees and the share of employees aged fifty of more. The other covariates have roughly the same impact on employment structure and hiring strategy and a comparable $\mathrm{R}^{2}$ to the estimations on the basis of wage differences (compare Table 5). These findings might be interpreted as support of the hypothesis that enterprises with high seniority wages defer payments and therefore pay higher wages for older employees than their productivity.

\section{Conclusions}

German establishments that pay a higher seniority wage than the average establishment in their sector can retain their employees longer than the average establishment. These establishments also hire less employees aged fifty or older (in relation to the number of employees aged fifty or the number of new hires with a seniority of less than five years). Seniority wages do not have an impact on the average employee age and the share of employees aged fifty or above, however, because both effects - longer seniority and less older employees hired - seem to cancel themselves out. This means that German establishments use deferred payments as an efficient device to retain and motivate their employees. As older newly hired workers are too expensive in these establishments, this practice may be one reason why older unemployed in Germany face 
bigger problems to get a new job than older unemployed in almost all other developed countries. This argument is supported by our findings that in international comparisons, German enterprises pay relatively high seniority wages on average.

The high seniority wages in Germany are not a consequence of institutional rules but paid voluntarily by the establishments because there are no binding clauses for example in collective bargaining contracts that force enterprises to increase wages with seniority (Bispinck, 2006). The pattern observed may be a consequence of deferred compensation which implies that earnings increase stronger than productivity. It may also stem from human capital improvements - training or learning on the job leads to higher productivity with increasing seniority. In these enterprises it may in addition not be worthwhile to hire older employees because they do not have enough tenure left to reap their full productivity after a lengthy training-on-the-job period. This explanation does not rule out, however, that the earnings pattern is steeper than the productivity pattern in these enterprises (Carmichael, 1983). In order to separate both explanations empirically, it would be necessary to test if enterprises with strong seniority payments also pay more than proportionate retirement payments when employees leave the enterprise before the official retirement age (Lazear, 1979). Another option is to relate seniority wages to employee supervision costs (Hutchens, 1987). Both options are not viable with our data set, however, because we cannot observe retirement payments or control costs. This question therefore has to be left to future research.

\section{Literature}

Abraham, Katherine und Henry Farber (1987): Job Duration, Seniority, and Earnings, American Economic Review 77 (3): 278-297.

Addison, John, Paulino Teixeira, and Thomas Zwick (2006): German Works Councils and the Anatomy of Wages, ZEW Discussion Paper 06-034, Mannheim.

Alda, Holger, Stefan Bender, and Hermann Gartner (2005): The linked employeremployee dataset of the IAB (LIAB), IAB Discussion Paper 06/2005, Nuremberg.

Altonji, Joseph and Robert Shakotko (1987): Do Wages Rise with Job Seniority? Review of Economic Studies 54, 437-459.

Bispinck, Benedikt (2006): Senioritätsregeln in Tarifverträgen, in: Deutsches Zentrum für Altersfragen (ed.): Beschäftigungssituation älterer Arbeitnehmer, Berlin: 129 200. 
Buhai, Sebastian, Miguel Portela, Coen Teulings und Aico van Vuuren (2007): Returns to Seniority: Time or Rank?, mimeo Tinbergen Institute, Rotterdam.

Carmichael, Lorne (1983): Firm-Specific Human Capital and Promotion Ladders, Bell Journal of Economics 14: 251-258.

Daniel, Kirsten und John Heywood (2007): The Determinants of Hiring Older Workers: UK Evidence, Labour Economics 14 (1): 35-51.

Dustmann, Christian and Costas Meghir (2005): Wages, Experience and Seniority, Review of Economic Studies, 72 (1): 77-108

Dustmann, Christian and Sonia Pereira (2005): Wage Growth and Job Mobility in the UK and Germany, IZA Discussion Paper 1586, Bonn.

Farber, Henry (1997): The Changing Face of Job Loss in the United States, 1981-1995, Brookings Papers on Economic Activity: Microeconomics, 55-128.

Gartner, Hermann (2005): The imputation of wages above the contribution limit with the German IAB employment sample, FDZ Methodenreport Nr. 02/2005, Nuremberg.

Harris, Milton and Bengt Holmstrom (1982): A Theory of Wage Dynamics, Review of Economic Studies 49 (3): 315-353.

Hellerstein, J., D. Neumark, and K. Troske (1999): Wages, productivity, and worker characteristics: evidence from plant-level production functions and wage equations, Journal of Labor Economics, 17 (3): 409-446.

Hellerstein, J. and D. Neumark (2004): Production function and wage equation estimation with heterogenous labor: evidence from a new matched employer employee data set, NBER Working Paper 10325, Cambridge, Mass..

Hirsch, Barry, David Macpherson, and Melissa Hardy (2000): Occupational Age Structure and Access for Older Workers, Industrial and Labor Relations Review 51: 401-418.

Hutchens, Robert (1986): Delayed Payment Contracts and a Firm's Propensity to Hire Older Workers, Journal of Labor Economics 4 (4): 439-457.

Hutchens, Robert (1987): A Test of Lazear's Theory of Delayed Payment Contracts, Journal of Labor Economics 5 (4): 153-170.

Hutchens, Robert (1989): Seniority, Wages and Productivity: A Turbulent Decade, Journal of Economic Perspectives 3 (4): 49-64. 
Lazear, Edward (1979): Why is there mandatory retirement? Journal of Political Economy 87: 1261-1284.

Lazear, Edward (1981): Agency, earnings profiles productivity and hours restrictions, American Economic Review 71: 606-620.

Lazear, Edward (1999): Personnel Economics: Past Lessons and Future Directions, Journal of Labor Economics 17 (2): 199-236.

Lefranc, Arnaud (2003): Labor Market Dynamics and Wage Losses of Displaced Workers in France and the United-States, William Davidson Institute Working Paper 614.

Medoff, James, and Katherine Abraham (1980): Experience, Performance and Earnings, Quarterly Journal of Economics 95: 703-736.

OECD (2005): Ageing and Employment Policies - Germany, Paris.

OECD (2008): SourceOECD, Paris. (http://stats.oecd.org/)

Parent, Daniel (2000): Industry-Specific Capital and the Wage Profile: Evidence from the NLSY and PSID, Journal of Labor Economics 13 (4): 653 - 677.

Schief, Sebastian (2006): Beschäftigungsquoten, Arbeitszeiten und Arbeitsvolumina in der Europäischen Union, der Schweiz und Norwegen, in: Deutsches Zentrum für Altersfragen (ed.): Beschäftigungssituation älterer Arbeitnehmer, Berlin: 53 - 92.

Shaw, Kathryn and Edward Lazear (2007): Tenure and Output, NBER working paper 13652, Cambridge, MA.

Topel, Robert (1991): Specific Capital, Mobility, and Wages: Wages Rise with Job Seniority, Journal of Political Economy 99 (1): 145-176.

Williams, Nicolas (2004): Seniority, Experience, and Wages in the UK, mimeo University of Cincinnati, Cincinnati. 
Table 1: Yearly wage growth for employees staying in the establishment, dependent variable: $\ln ($ yearly real wage change), West-German males

\begin{tabular}{|c|c|c|c|c|}
\hline & \multicolumn{2}{|l|}{ All } & \multicolumn{2}{|l|}{ Men } \\
\hline & & Std. & & Std. \\
\hline & Coef. & Dev. & Coef. & Dev. \\
\hline$\Delta$ experience and seniority & $0.115 * * *$ & 0.001 & $0.116 * * *$ & 0.001 \\
\hline$\Delta$ seniority $^{2} * 100$ & $-0.218 * * *$ & 0.003 & $-0.217 * * *$ & 0.003 \\
\hline$\Delta$ seniority $^{3 *} 1000$ & $0.081 * * *$ & 0.001 & $0.080 * * *$ & 0.001 \\
\hline$\Delta$ seniority $^{4} * 10000$ & $-0.010 * * *$ & 0.000 & $-0.009 * * *$ & 0.000 \\
\hline$\Delta$ experience $^{2} * 100$ & $-0.621 * * *$ & 0.006 & $-0.596 * * *$ & 0.008 \\
\hline$\Delta$ experience $^{3 *} 1000$ & $0.211 * * *$ & 0.002 & $0.196 * * *$ & 0.003 \\
\hline$\Delta$ experience $^{4 *} 10000$ & $-0.027 * * *$ & 0.000 & $-0.024 * * *$ & 0.000 \\
\hline Number of observations & 5305623 & & 3980980 & \\
\hline $\mathrm{R}^{2}$ & 0.02 & & 0.02 & \\
\hline
\end{tabular}

Source: LIAB Cross Section Version, Waves 1998-2004 
Table 2: Explanation of job entry wages, dependent variable: estimated real wage at tenure $=0$, West German males

\begin{tabular}{|c|c|c|c|c|}
\hline & \multicolumn{2}{|l|}{ All } & \multicolumn{2}{|l|}{ Men } \\
\hline & \multicolumn{2}{|r|}{ Std. } & \multirow[b]{2}{*}{ Coef. } & Std. \\
\hline & Coef. & Dev. & & Dev. \\
\hline Experience at job start & $0.056 * * *$ & 0.000 & $0.061 * * *$ & 0.061 \\
\hline $\begin{array}{l}\text { Secondary education without professional } \\
\text { degree }\end{array}$ & $-0.040 * * *$ & 0.001 & $-0.056 * * *$ & -0.056 \\
\hline $\begin{array}{l}\text { Secondary education with professional } \\
\text { degree }\end{array}$ & $-0.068 * * *$ & 0.001 & $0.041 * * *$ & 0.041 \\
\hline Tertiary education with professional degree & $0.295 * * *$ & 0.000 & $0.294 * * *$ & 0.294 \\
\hline University of Applied Sciences & $0.504 * * *$ & 0.002 & $0.482 * * *$ & 0.482 \\
\hline University & $0.656 * * *$ & 0.001 & $0.632 * * *$ & 0.632 \\
\hline Foreigner & $0.005 * * *$ & 0.001 & $0.009 * * *$ & 0.009 \\
\hline Dummy 1999 & $0.027 * * *$ & 0.001 & $0.026 * * *$ & 0.028 \\
\hline Dummy 2000 & $0.029 * * *$ & 0.001 & $0.029 * * *$ & 0.026 \\
\hline Dummy 2001 & $0.038 * * *$ & 0.001 & $0.038 * * *$ & 0.017 \\
\hline Dummy 2002 & $0.064 * * *$ & 0.001 & $0.059 * * *$ & 0.004 \\
\hline Dummy 2003 & $0.112 * * *$ & 0.001 & $0.106 * * *$ & 0.001 \\
\hline Constant & $3.206 * * *$ & 0.001 & $3.149 * * *$ & 3.203 \\
\hline Number of observations & \multicolumn{2}{|l|}{4809951} & \multicolumn{2}{|c|}{3706202} \\
\hline $\mathrm{R}^{2}$ & \multicolumn{2}{|l|}{0.34} & \multicolumn{2}{|l|}{0.39} \\
\hline \multicolumn{5}{|c|}{ Estimated Cumulative Return to Job Tenure for Men } \\
\hline & \multicolumn{2}{|l|}{5 years } & \multicolumn{2}{|c|}{20 years } \\
\hline West Germany 1998-2003 & \multicolumn{2}{|l|}{0.23} & 0.56 & 0.73 \\
\hline Topel (1991) for USA 1968-1983 & 0.18 & 25 & 0.28 & 0.34 \\
\hline Lefranc (2003) for USA 1981-1992 & 0.06 & 11 & 0.15 & 0.19 \\
\hline Lefranc (2003) for France 1990-1997 & 0.08 & 15 & 0.20 & 0.25 \\
\hline
\end{tabular}

Source: LIAB Cross Section Version, Waves 1998-2004 
Table 3: Explanation of log wages, West German males

\begin{tabular}{|c|c|c|c|c|}
\hline & \multicolumn{2}{|c|}{ OLS regression } & \multicolumn{2}{|c|}{$\begin{array}{l}\text { Instrumental variables } \\
\text { regression IVten }{ }^{1}\end{array}$} \\
\hline & & Std. & & Std. \\
\hline & Coef. & Dev. & Coef. & Dev. \\
\hline Seniority & $0.007 * * *$ & 0.001 & 0.003 & 0.003 \\
\hline Seniority squared & $-0.001 * * *$ & 0.000 & -0.000 & 0.000 \\
\hline More than one year of seniority & $0.103 * * *$ & 0.006 & $0.047 * * *$ & 0.003 \\
\hline Experience in years & $0.064 * * *$ & 0.002 & $0.070 * * *$ & 0.002 \\
\hline Experience squared & $-0.028 * * *$ & 0.001 & $-0.030 * * *$ & 0.001 \\
\hline Experience tripled & $0.004 * * *$ & 0.000 & $0.005 * * *$ & 0.000 \\
\hline $\begin{array}{l}\text { Secondary education without professional } \\
\text { degree }\end{array}$ & $-0.116 * * *$ & 0.018 & $-0.107 * * *$ & 0.017 \\
\hline $\begin{array}{l}\text { Secondary education with professional } \\
\text { degree }\end{array}$ & $0.094 * * *$ & 0.017 & $0.104 * * *$ & 0.017 \\
\hline Tertiary education with professional degree & $0.352 * * *$ & 0.015 & $0.360 * * *$ & 0.016 \\
\hline University of Applied Sciences & $0.551 * * *$ & 0.018 & $0.554 * * *$ & 0.018 \\
\hline University & $0.677 * * *$ & 0.018 & $0.678 * * *$ & 0.018 \\
\hline Foreigner & -0.002 & 0.007 & 0.000 & 0.007 \\
\hline Dummy 1999 & $0.018 * * *$ & 0.003 & $0.017 * * *$ & 0.003 \\
\hline Dummy 2000 & $-0.027 * * *$ & 0.004 & $-0.028 * * *$ & 0.004 \\
\hline Dummy 2001 & -0.007 & 0.006 & $-0.010 * *$ & 0.005 \\
\hline Dummy 2002 & -0.011 & 0.007 & $-0.013 * *$ & 0.005 \\
\hline Constant & $3.90 * * *$ & 0.020 & $3.926 * * *$ & 0.019 \\
\hline Number of observations & 5224266 & & 522426 & \\
\hline $\mathrm{R}^{2}$ & 0.45 & & 0.45 & \\
\hline
\end{tabular}


Instrumental variables regression

IVtenexp ${ }^{2}$

\begin{tabular}{|c|c|c|}
\hline & Coef. & Std. Dev. \\
\hline Seniority & -0.001 & 0.002 \\
\hline Seniority squared & 0.000 & 0.000 \\
\hline More than one year of seniority & $0.054 * * *$ & 0.005 \\
\hline Experience in years & $0.041 * *$ & 0.021 \\
\hline Experience squared & -0.005 & 0.018 \\
\hline Experience tripled & -0.000 & 0.003 \\
\hline Secondary education without professional degree & $-0.116 * * *$ & 0.022 \\
\hline Secondary education with professional degree & $0.101 * * *$ & 0.019 \\
\hline Tertiary education with professional degree & $0.386 * * *$ & 0.027 \\
\hline University of Applied Sciences & $0.555 * * *$ & 0.018 \\
\hline University & $0.697 * * *$ & 0.027 \\
\hline Foreigner & 0.014 & 0.017 \\
\hline Dummy 1999 & 0.012 & 0.016 \\
\hline Dummy 2000 & $-0.037 * * *$ & 0.014 \\
\hline Dummy 2001 & $-0.020 * *$ & 0.009 \\
\hline Dummy 2002 & $-0.023 * * *$ & 0.004 \\
\hline Constant & $3.951 * * *$ & 0.029 \\
\hline Number of observations & \multicolumn{2}{|c|}{5224266} \\
\hline $\mathrm{R}^{2}$ & \multicolumn{2}{|c|}{0.42} \\
\hline
\end{tabular}

Notes: ${ }^{1}$ IVten - instrumented: tenure, tenure square, more than one year of tenure, ${ }^{2}$

IVtenexp - instrumented: tenure, tenure squared, more than one year of tenure, experience, experience squared, experience tripled.

Source: LIAB Cross Section Version, Waves 1998-2004 
Table 4: Cumulative returns to seniority

\begin{tabular}{lcccc}
\hline \hline & 5 years & 10 years & 15 years & 20 years \\
\hline West Germany 1998 - 2003 IVten & 0.06 & 0.08 & 0.09 & 0.10 \\
West Germany 1998 - 2003 IVtenexp & 0.05 & 0.05 & 0.05 & 0.05 \\
$\begin{array}{l}\text { Dustmann and Pereira (2005) for West } \\
\text { Germany 1991 - 1997 IVten }\end{array}$ & 0.01 & 0.02 & 0.04 & 0.06 \\
$\begin{array}{l}\text { Dustmann and Pereira (2005) for West } \\
\text { Germany 1991 - 1997 IVtenexp }\end{array}$ & -0.01 & -0.02 & -0.03 & -0.03 \\
$\begin{array}{l}\text { Altonji and Shakotko (1987) for USA } \\
\text { 1968 - 1981 IVten }\end{array}$ & 0.04 & 0.03 & 0.03 & 0.04 \\
\hline \hline
\end{tabular}

Table 5: Empirical consequences of deferred payments - wage differences, West

German males

\begin{tabular}{|c|c|c|c|c|}
\hline & \multicolumn{2}{|c|}{ Average employee age } & \multicolumn{2}{|c|}{ Share employees $50+$} \\
\hline & & Std. & & Std. \\
\hline & Coef. & Dev. & Coef. & Dev. \\
\hline Seniority wage & -0.375 & 1.492 & 0.007 & 0.041 \\
\hline $\begin{array}{l}\text { Share secondary education without } \\
\text { prof. qual. }\end{array}$ & $1.037 * * *$ & 0.348 & $0.040 * * *$ & 0.011 \\
\hline $\begin{array}{l}\text { Share secondary education with prof. } \\
\text { qual. }\end{array}$ & -0.331 & 0.265 & $0.018 * *$ & 0.008 \\
\hline $\begin{array}{l}\text { Share tertiary education with prof. } \\
\text { qual. }\end{array}$ & $-3.445 * * *$ & 0.776 & $-0.123 * * *$ & 0.021 \\
\hline Share polytechnics & $5.488 * * *$ & 0.879 & $0.129 * * *$ & 0.037 \\
\hline Share university & $2.556 * * *$ & 0.596 & $0.061 * * *$ & 0.019 \\
\hline Share foreigner & $-1.468 * * *$ & 0.519 & 0.004 & 0.016 \\
\hline Works council & $2.232 * * *$ & 0.129 & $0.055 * * *$ & 0.004 \\
\hline Export dummy & $0.438 * * *$ & 0.146 & -0.006 & 0.005 \\
\hline$\underline{\text { Profit situation }}$ & $-1.369 * * *$ & 0.150 & $-0.035 * * *$ & 0.004 \\
\hline Number of Observations & 27362 & & 27362 & \\
\hline $\mathrm{R}^{2}$ & 0.09 & & 0.06 & \\
\hline
\end{tabular}




\begin{tabular}{|c|c|c|c|c|}
\hline & \multicolumn{2}{|c|}{ Average Seniority } & \multicolumn{2}{|c|}{$\begin{array}{c}\begin{array}{c}\text { New employees } 50+/ \\
\text { employees } 50+\end{array} \\
\end{array}$} \\
\hline & \multicolumn{2}{|r|}{ Std. } & \multicolumn{2}{|r|}{ Std. } \\
\hline & Coef. & Dev. & Coef. & Dev. \\
\hline Seniority wage & $6.647 * * *$ & 1.350 & $-0.115 * * *$ & 0.022 \\
\hline $\begin{array}{l}\text { Share secondary education without } \\
\text { professional qualification }\end{array}$ & $3.126 * * *$ & 0.288 & $-0.015 * * *$ & 0.008 \\
\hline Share secondary education with prof. qual. & $3.760 * * *$ & 0.195 & $-0.027 * * *$ & 0.006 \\
\hline Share tertiary education with prof. qual. & 0.602 & 0.526 & -0.058 & 0.013 \\
\hline Share polytechnics & $2.300 * * *$ & 0.724 & 0.011 & 0.019 \\
\hline Share university & $1.397 * * *$ & 0.513 & -0.015 & 0.011 \\
\hline Share foreigner & $-2.913 * * *$ & 0.416 & 0.013 & 0.011 \\
\hline Works council & $1.640 * * *$ & 0.130 & 0.001 & 0.002 \\
\hline Export dummy & $0.594 * * *$ & 0.158 & $-0.008 * * *$ & 0.003 \\
\hline Profit situation & $-1.062 * * *$ & 0.151 & $-0.005 *$ & 0.003 \\
\hline Number of Observations & 27362 & & 27362 & \\
\hline $\mathrm{R}^{2}$ & 0.19 & & 0.05 & \\
\hline
\end{tabular}

New employees 50+/all new hires

\begin{tabular}{lcr}
\hline & Coef. & Std. Dev. \\
\hline Seniority wage & $-0.128 * * *$ & 0.032 \\
Share secondary education without prof. qual. & 0.000 & 0.008 \\
Share secondary education with prof. qual. & $-0.013 * *$ & 0.006 \\
Share tertiary education with prof. qual. & $-0.054 * * *$ & 0.020 \\
Share polytechnics & 0.014 & 0.020 \\
Share university & -0.011 & 0.013 \\
Share foreigner & -0.015 & 0.011 \\
Works council & 0.004 & 0.003 \\
Export dummy & $-0.008 * *$ & 0.004 \\
Profit situation & $-0.016 * * *$ & 0.003 \\
\hline Number of Observations & 25311 & \\
$\mathrm{R}^{2}$ & 0.03 & \\
\hline \hline
\end{tabular}

Comments: OLS regressions clustered by establishment number. Regressions include a constant, year dummies, five firm size dummies, and 16 sector dummies.

Source: LIAB Cross Section Version, Waves 1998-2004 
Table 6: Empirical consequences of deferred payments - wage levels, West German males

\begin{tabular}{|c|c|c|c|c|}
\hline & \multicolumn{2}{|c|}{ Average employee age } & \multicolumn{2}{|c|}{ Share employees $50+$} \\
\hline & & & & Std. \\
\hline & Coef. & Std. Dev. & Coef. & Dev. \\
\hline Dummy strong seniority wage & 0.010 & 0.132 & -0.001 & 0.003 \\
\hline $\begin{array}{l}\text { Share secondary education without } \\
\text { prof. qual. }\end{array}$ & 0.568 & 0.450 & $0.019 *$ & 0.011 \\
\hline $\begin{array}{l}\text { Share secondary education with prof. } \\
\text { qual. }\end{array}$ & $1.131 * * *$ & 0.339 & $0.023 * * *$ & 0.008 \\
\hline $\begin{array}{l}\text { Share tertiary education with prof. } \\
\text { qual. }\end{array}$ & -0.222 & 1.012 & $-0.057 * * *$ & 0.018 \\
\hline Share polytechnics & $4.298 * * *$ & 0.851 & $0.086 * * *$ & 0.028 \\
\hline Share university & $3.011 * * *$ & 0.612 & $0.024 *$ & 0.014 \\
\hline Share foreigner & $-3.178 * * *$ & 0.637 & -0.019 & 0.014 \\
\hline Works council & $1.931 * * *$ & 0.158 & $0.047 * * *$ & 0.004 \\
\hline Export dummy & 0.235 & 0.155 & 0.004 & 0.004 \\
\hline Profit situation & $-0.611 * * *$ & 0.160 & $-0.011 * * *$ & 0.004 \\
\hline Number of Observations & 6169 & & 6169 & \\
\hline $\mathrm{R}^{2}$ & 0.08 & & 0.06 & \\
\hline
\end{tabular}




\begin{tabular}{|c|c|c|c|c|}
\hline & \multicolumn{2}{|c|}{ Average Seniority } & \multicolumn{2}{|c|}{$\begin{array}{l}\text { New employees } \\
50+/ \text { Number } \\
\text { employees } 50+\end{array}$} \\
\hline & Coef. & $\begin{array}{l}\text { Std. } \\
\text { Dev. }\end{array}$ & Coef. & $\begin{array}{l}\text { Std. } \\
\text { Dev. }\end{array}$ \\
\hline Dummy strong seniority wage & $0.639 * * *$ & 0.123 & $-0.012 * * *$ & 0.002 \\
\hline $\begin{array}{l}\text { Share secondary education without prof. } \\
\text { qual. }\end{array}$ & $2.359 * * *$ & 0.544 & $-0.013 *$ & 0.008 \\
\hline Share secondary education with prof. qual. & $4.652 * * *$ & 0.407 & $-0.013 * *$ & 0.006 \\
\hline Share tertiary education with prof. qual. & 0.914 & 1.344 & $-0.035 * * *$ & 0.012 \\
\hline Share polytechnics & 1.256 & 1.131 & -0.001 & 0.011 \\
\hline Share university & $2.633 * * *$ & 0.729 & $-0.024 * *$ & 0.008 \\
\hline Share foreigner & $-2.002 * * *$ & 0.755 & -0.004 & 0.010 \\
\hline Works council & $2.103 * * *$ & 0.185 & 0.002 & 0.003 \\
\hline Export dummy & $0.445 * *$ & 0.213 & -0.004 & 0.003 \\
\hline Profit situation & $-0.694 * * *$ & 0.149 & -0.000 & 0.003 \\
\hline Number of Observations & 6169 & & 6169 & \\
\hline $\mathrm{R}^{2}$ & 0.18 & & 0.06 & \\
\hline
\end{tabular}


Table 6 continued

New employees 50+/All new hired

\begin{tabular}{lcr}
\hline & Coef. & Std. Dev. \\
\hline Dummy strong seniority wage & $-0.008^{*}$ & 0.004 \\
Share secondary education without prof. qual. & -0.010 & 0.014 \\
Share secondary education with prof. qual. & -0.216 & 0.043 \\
Share tertiary education with prof. qual. & -0.184 & 0.101 \\
Share polytechnics & -0.081 & 0.104 \\
Share university & -0.259 & 0.070 \\
Share foreigner & $-0.045^{* *}$ & 0.020 \\
Works council & $0.017 * * *$ & 0.006 \\
Export dummy & -0.006 & 0.006 \\
Profit situation & $-0.009 *$ & 0.006 \\
\hline Number of Observations & 5819 & \\
$\mathrm{R}^{2}$ & 0.03 & \\
\hline \hline
\end{tabular}

Comments: OLS regression with heterogeneity robust variances. Regressions include 16 sector dummies and four firm size dummies.

Source: LIAB Cross Section Version, Waves 1998-2004 
Appendix Table 1: Descriptive statistics of variables used

\begin{tabular}{|c|c|c|}
\hline \multicolumn{3}{|c|}{ Average } \\
\hline Variable & Value & Description \\
\hline Seniority & 11.08 & Years of seniority, imputed \\
\hline Experience & 16.54 & Years of experience, imputed \\
\hline Experience at job start & 5.90 & $\begin{array}{l}\text { Years of experience in current job at } \\
\text { seniority equals zero }\end{array}$ \\
\hline More than one year of seniority & 0.90 & $\begin{array}{l}\text { Dummy, } 1=\text { seniority longer than } 1 \text { year, } \\
0=\text { otherwise }\end{array}$ \\
\hline Wage & 4.56 & log wage, imputed \\
\hline $\begin{array}{l}\text { Secondary education without prof. } \\
\text { qual. }\end{array}$ & 0.16 & $\begin{array}{l}\text { Dummy, } 1=\text { highest school education } \\
\text { secondary education without professional } \\
\text { qualification, } 0=\text { otherwise }\end{array}$ \\
\hline Secondary education with prof. qual. & 0.62 & $\begin{array}{l}\text { Dummy, } 1=\text { highest school education } \\
\text { secondary education with professional } \\
\text { qualification, } 0=\text { otherwise }\end{array}$ \\
\hline $\begin{array}{l}\text { Tertiary education without prof. qual. } \\
\text { (reference) }\end{array}$ & 0.01 & $\begin{array}{l}\text { Dummy, } 1=\text { highest school education } \\
\text { tertiary education without professional } \\
\text { qualification, } 0=\text { otherwise }\end{array}$ \\
\hline Tertiary education with prof. qual. & 0.05 & $\begin{array}{l}\text { Dummy, } 1=\text { highest school education } \\
\text { tertiary education with professional } \\
\text { qualification, } 0=\text { otherwise }\end{array}$ \\
\hline Polytechnics & 0.05 & $\begin{array}{l}\text { Dummy, } 1=\text { highest school education } \\
\text { university of applied sciences, } \\
0=\text { otherwise }\end{array}$ \\
\hline University & 0.07 & $\begin{array}{l}\text { Dummy, } 1=\text { highest school education } \\
\text { university, } 0=\text { otherwise }\end{array}$ \\
\hline Foreigner & 0.10 & Dummy, $1=$ foreigner, $0=$ German \\
\hline Works council & 0.91 & $\begin{array}{l}\text { Dummy, } 1=\text { works council present, } \\
0=\text { otherwise }\end{array}$ \\
\hline Export dummy & 0.41 & Dummy, $1=$ exporter, $0=$ otherwise \\
\hline Profit situation & 0.28 & $\begin{array}{l}\text { Dummy, } 1=\text { profit situation better than at } \\
\text { competitors, } 0=\text { otherwise }\end{array}$ \\
\hline Average employee age & 40.31 & Average age of employees \\
\hline Share employees $50+$ & 0.21 & Dummy, $1=$ older than $50,0=$ otherwise \\
\hline New employees $50+/$ employees $50+$ & 0.04 & $\begin{array}{l}\text { Number of employees with less than } 5 \\
\text { years of seniority who have been hired } \\
\text { after the age of } 50 \text { divided by employees } \\
\text { older than } 50\end{array}$ \\
\hline New employees $50+/$ all new hires & 0.28 & $\begin{array}{l}\text { Number of employees with less than } 5 \\
\text { years of seniority who have been hired } \\
\text { after the age of } 50 \text { divided by employees } \\
\text { with less than } 5 \text { years of seniority }\end{array}$ \\
\hline
\end{tabular}


Appendix Figure 1: International comparison of seniority wages

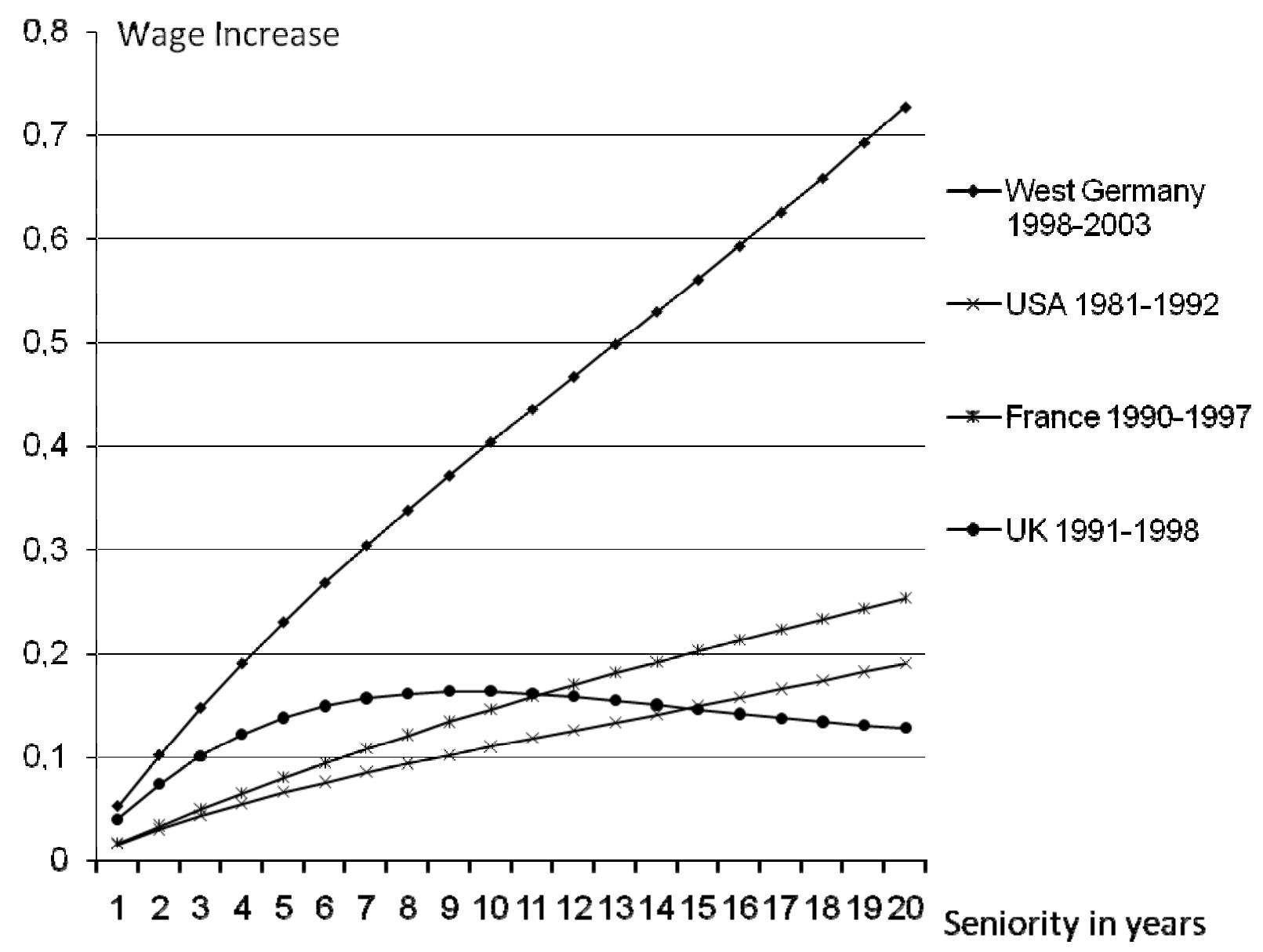

